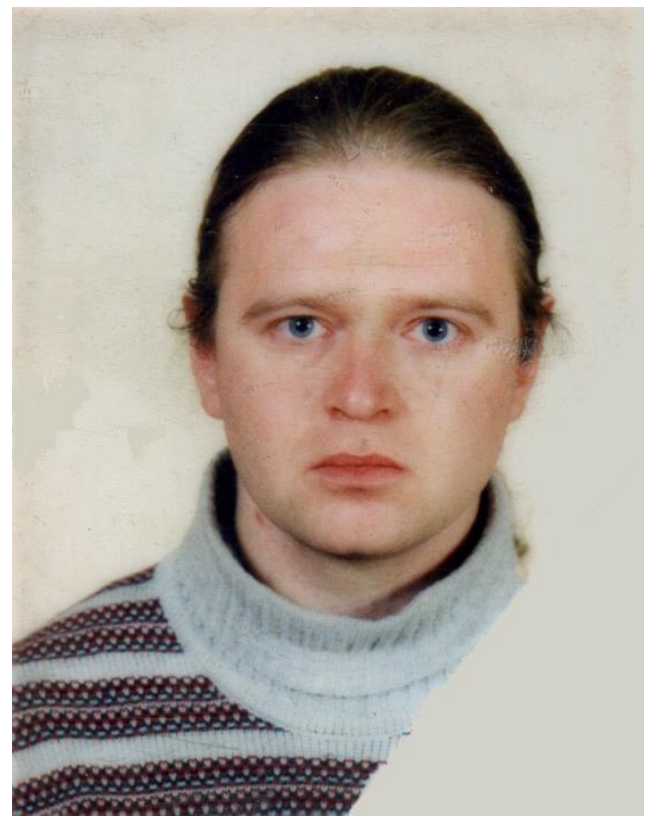

\author{
GREBNEV \\ Yaroslav V., \\ postgraduate student of National \\ Scientific Agricultural Library \\ of NAAS,
}

Kyiv, Ukraine

yargrebnev@eml.ru

\title{
THE LIFE OF PRINCE S.P. URUSOV (1859 - 1918): UNKNOWN PAGES
}

Prince Sergei Petrovich Urusov is known for his work in the field of agricultural animal husbandry. Being a contemporary and associate of the fundamental figures of Russian animal husbandry, such as N. P. Chirvinsky, P. N. Kuleshov. E. F. Liskun, A. I. Pridorogin, E. A. Bogdanov and others, he left a fairly large book heritage, which is still of great importance in agriculture. The main attention in his activity is paid to horse breeding and equestrian sports, goat breeding and poultry breeding, although he has some printed works on general animal husbandry, hunting, cattle, pig breeding. For a long time, nothing was said about his merits due to his belonging to the upper class of the Russian Empire.

This article is the first attempt at compiling a biography and a socio-historical portrait of Prince Sergei Petrovich Urusov. In the article we list the factors that influenced the formation of the personality of the scientist, the military and public service of Prince Sergei Urusov at various posts, his charitable, social and scientificliterary activities, the history of his arrest and tragic death.

Key words: Prince Sergei Petrovich Urusov, horse breeding, goat breeding, history of animal husbandry, Elizabethan charity society, Russian-Turkish war of 1877 - 1878, Her Majesty's Leib-Dragoon Pskov regiment, Red Terror.

\section{ЖИТТЕВИЙ ШЛЯХ КНЯЗЯ С.П. УРУСОВА (1859 - 1918): НЕВІДОМІ СТОРІНКИ}

Князь Сергій Петрович Урусов відомий своєю роботою в галузі сільськогосподарського тваринництва. Будучи сучасником $і$ сподвижником основоположних фігур вітчизняного тваринництвва, таких як М. П. Чирвінський, П. М. Кулєшов. Ю. Ф. Лискун, М. І. Придорогін, 
С.А. Богданов та ін., він залишив досить велику книжкову спадщчину, яка навіть до сьогодні має важливе значення в сільському господарстві. Головну увагу в своїй діяльності він приділяв конярству та кінному спорту, козівництву i птахівництву, хоча у нього є роботи присвячені загальному тваринництву, питанням мисливства, великій рогатій худобі, свинарству. Протягом довгого часу про його заслуги нічого не говорилося внаслідок його приналежності до вищого стану Російської імперії.

Дана стаття є першою спробою складання його біографії $і$ соиіальноісторичного портрету. У статті наводяться фактори, що вплинули на формування особистості вченого, описується військова $і$ державна служба князя С. П. Урусова на різних постах, його благодійна, громадська та науковолітературна діяльність, історія його арешту і трагічна загибель.

Ключові слова: Князь Сергій Петрович Урусов, конярство, козівництво, історія тваринниитва, Слизаветинське благодійне товариство, Російськотуреиька війна 1877-1878 рр., Лейб-Драгунський Псковський Ї̈ Величності полк, червоний терор.

\section{ЖИЗНЕННЫЙ ПУТЬ КНЯЗЯ С.П. УРУСОВА (1859 - 1918): НЕИЗВЕСТНЫЕ СТРАНИЦЫ}

Князь Сергей Петрович Урусов известен своей работой в области сельскохозяйственного животноводства. Будучи современником и сподвижником основополагающих фигур отечественного животноводства, таких как Н. П. Чирвинский, П. Н. Кулешов. Е. Ф. Лискун, А. И. Придорогин, E. А. Богданов и др., он оставил достаточно большое книжное наследие, до сих пор имеющее немаловажное значение в сельском хозяйстве. Основное внимание в своей деятельности он уделял коневодству и конному спорту, козоводству и птицеводству, хотя у него есть работы, посвященные общему животноводству, вопросам охоть, крупному рогатому скоту, свиноводству. $B$ течение долгого времени о его заслугах ничего не говорилось вследствие его принадлежности к высшему сословию Российской империи.

Данная статья является первой попыткой составления его биографии и сочиально-исторического портрета. B статье приводятся факторы, повлиявшие на формирование личности ученого, описывается военная и государственная служба князя С. П. Урусова на разных постах, его благотворительная, общественная и научно-литературная деятельность, история его ареста и трагическая гибель.

Ключевые слова: Князь Сергей Петрович Урусов, коневодство, козоводство, история животноводства, Елизаветинское благотворительное общество, Русско-туреикая война 1877 - 1878 г2., Лейб-Драгунский Псковский Ее Величества полк, красный террор. 


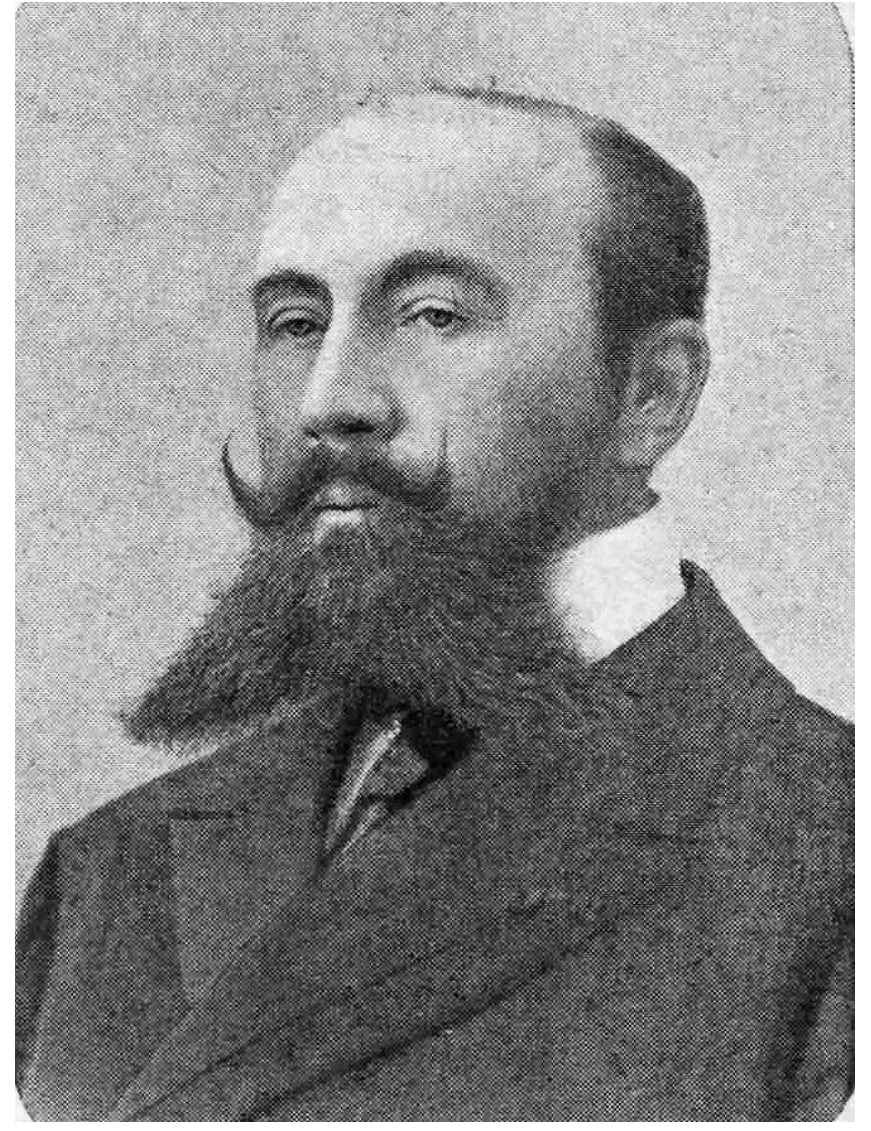

Prince Sergei Petrovich Urusov

1859 - 1918

The formation and development of Russian zootechnical science can be considered as a merit of a constellation of prominent Russian scientists who worked at the turn of the 19th and 20th centuries. Among these names we see Prince Sergei Petrovich Urusov, who, having an outstanding literary, research and organizational talent, very organically fit into the activities of this team. Accordingly, not mentioning his activities in these years is a very noticeable gap for the history of Russian zootechnical science as a whole.

Unlike other founders of Russian zootechnical science, for a long time there was nothing said about Prince Sergei Petrovich Urusov, due to his belonging to the upper class of the Russian Empire. Accordingly, the biography and scientific activities of Prince Sergei Petrovich Urusov have not been studied yet. However, relatively recently, an excellent study by K. Nedrya and P. Chernobay about his brother Nikolai (1863 - 1918) [2] was published in Ukraine. Despite the fact that Nikolai Urusov is not an author of scientific works on animal husbandry, he is still a bright and illustrative representative of his family, undoubtedly having a lot in common with Sergei.

The purpose of our study is to reveal the main milestones in the life and creative path of Prince Sergei Petrovich Urusov, his contribution to the development of Russian animal husbandry as a science and highlighting other areas of his activity. The research is based on the use of general scientific principles of consistency, complexity, multifactoriality and comprehensiveness, which provide a holistic coverage of the issue. General scientific, interdisciplinary and special historical 
methods, as well as methods of source study and archival analysis are used. Preference has given to the biographical method as the main instrument of reconstructing the intellectual biography of a scientist. The source base of the study covers a wide range of published and unpublished materials; it is based on archival documents and works of Prince Sergei Urusov himself.

\section{Origin and family}

Prince Sergei Petrovich Urusov comes from the Moscow branch of the old and glorious princely lineage of the Urusovs. There is a classic work on the origin and merits of this dynasty, compiled by A. Narbut on the basis of archival research. In addition to the work of Narbut, it has been studied in the book of modern Ukrainian researchers K. Nedrya and P. Chernobay dedicated to Prince Nikolai Petrovich Urusov, the brother of Prince Sergei. From the extensive information given in these sources, we shall note that the Urusov family originates from Edigei Mangit (turn of the 14-15 centuries), a temnik (rank of a commander of 10,000 soldiers) of the Golden Horde, the founder of the ruling dynasty of the Nogai Horde. At the same time, the more distant ancestors of the Urusov princes ascend to Abu-Bakr (7 century) - a friend and associate of the Prophet Mohammed. Many ruling dynasties of the East traced their ancestry to Abu Bakr. The ancestor of the actual Russian princes Urusovs was Prince Urus (1489 - 1590), Edigei Mangit's descendant in the sixth generation, who at the end of his life ruled the Great Nogai Horde [1, 2].

\section{Parents' influence}

The extent of father's influence on the formation of Prince Sergei's personality can be deduced from the formular lists (service records, that included the individuals' biographical information, employment and official service history) of military service at our disposal. At an early stage, Sergei's path looks like an exact repetition of his father's. Before being admitted into the officer rank, both showed courage in the war against the Turks, for which they were decorated, after which both served for some time at the Kexholm grenadier regiment. It can be seen from this that Sergei fully inherited the courage of his father, being similar to him in many other features $[3,9]$. However, at the end of his military service, Sergei went along his own, special and 
somewhat unique way. Among the factors that shaped the life of Petr Urusov's family, we should note his friendship with the fundamental figures of the Golden Age of Russian literature, Pushkin and Lermontov [12]. Deeply affected by this influence, Petr Alexandrovich Urusov (1810 - 1890) apparently paid much attention to the importance of the literary word throughout his subsequent life, and it was the main factor that determined the development of the philological talent of his children, Sergei in particular. Speaking about the Urusov family, one should not forget about the maternal ancestors. Although the parents of prince Sergei's mother Ekaterina Nikolaevna Urusova (née Sipyagina) (1827 - 1894) died shortly after her birth, and she did not know them at all, she was well informed about them by her relatives, and they always and in everything were an example for her. Indeed, her father, General Nikolai Martemyanovich Sipyagin (1875 - 1828), in many ways resembles his grandchildren. Undoubtedly, Ekaterina Nikolaevna managed to cultivate the main qualities of her outstanding father in her children.

According to his contemporaries, Petr Alexandrovich Urusov led a riotous lifestyle, but after his marriage he "got under the thumb of his wife" [2]. This is hardly true. Considering the principles of noble honor, always sacredly observed in his family, and the 18-year age difference between the spouses, this is nothing more than vulgar jokes, possibly generated by envy and bordering on backbiting. However, from this gossip it follows that Ekaterina Nikolaevna had a firm independent character, was active, had the ability to lead, and, despite her age, could in many ways be on a par with her husband, the head of the family.

It does not make sense arguing which of the parents had a greater influence on the formation of the children's personalities, and it would be reasonable to assume their equal participation. Therefore, the children of Prince Petr Urusov equally inherited the qualities of both the Urusovs and the Sipyagins.

\section{Brothers and sisters}

In total, 11 children were born in the family of princes Petr Alexandrovich and Ekaterina Nikolaevna, and Sergei was the eighth child [1]. Apart from the parents, the children of Prince Urusov were undoubtedly influenced by the eldest daughter 
Elizaveta, who was much older than the other children. For example, she rallied all her younger sisters around herself, organizing a women's collective of writers and translators. The first serious work of this group was the translation of Boleslav Markevich's novel The Neglected Question into English, published in London in 1874. In 1876, a group of four sisters published a literary collection with the original title: Между нами: Recueil polyglotte: A litterary miscellany verfasst von Frauenhand в пользу бедньх. The collection contained works in four languages, and the sisters reflected it in the title of the book. Here, each of the Urusov princesses took a creative pseudonym: Elizaveta - Pantesilee, Maria - Basileia, Sophia Meminia, Ekaterina - Nandi [4]. The collection demonstrates the level of philological and linguistic training of the girls. For example, Ekaterina has published her translation of the epic about Ilya Muromets into Old English, and it shows the depth of her knowledge and mastery of the language. The compilers of the Brockhaus and Efron Encyclopedic Dictionary mention that Sofya Petrovna "translated a lot into English": Golitsyn in his Dictionary of Female Writers mentions "Solovki" by Nemirovich-Danchenko, "The Riot of Stenka Razin" by Kostomarov , "Tales of the Cat-Purr" by Wagner [4]. In 1916, an article by A. N. Brenchaninov, "Ideological foundations of Russian Slavonism", was published in London in her translation. In 1917, she authored a book in English The Russian Soldier-peasant. In 1924, her story "Fireflies" (Lucciole) was published in Italy [5]. Thus, the Urusov sisters, one way or another, made their modest contribution to the development of the Golden Age of Russian literature.

Judging from the values and ideals of this family, and taking into account the literary heritage of the Urusov brothers, there is no doubt that both Sergei and his other brothers were not much inferior to their sisters in terms of humanitarian training.

The Urusov family was strong and close-knit; brothers and sisters throughout their life tried to support each other in everything, maintaining close communication. Elizaveta and Ekaterina lived for many years with Sergei and his family [10], which 
can be considered as additional evidence of the spiritual proximity between them and the commonality of literary interests.

The biographical materials of the members of the Urusov family, even such dry and fragmentary as the formular lists [3, 6, 7, 9], show the similarity of their biographies and destinies. Indeed, if we consider Sergei's military service, we see a number of striking coincidences with the events in the life of his father 50 years earlier. Later, his fate would bear a clear similarity with that of his brother Vladimir. But at the same time, Sergei, like all other members of his family, was a bright and unique personality. The similarity in many respects among the members of the Urusov family was not only genetically determined, the style of their upbringing played a great role, too. As K. Nedrya and P. Chernobay emphasized, the Urusov family did not focus on success, but rather on the ideal. The interests of the family and the service for the motherland were placed above all else [1]. Along with this, a healthy, conscious religios practice, moral ideals, and the desire for charitable activities were cultivated. The concept of the ideal was reinforced in the family by the living examples: those of Pushkin, Lermontov and General Sipyagin were, apparently, among the most important. The result of such an upbringing was that the Urusov family, as we see even from the scant information that has come down to us, was an integral well-coordinated body. There was unanimity in almost everything, from political convictions to economic interests [1]. Sergei would later benefit from this way of family organization in his work on the Russian Goat-Breeding Society.

The eldest of the brothers, Alexander, had been writing articles in agricultural magazines since the mid-1880s, successfully introducing progressive methods of farming on his estate and bringing its economy to the level of the best in Russia. Like Sergei, he owned several stud farms. Alexander differed from other family members, perhaps with the exception of Nikolai, in that he was a bright political figure, an activist of the State Duma. His convictions and aspirations are representative of the ideological mood of the Urusuov family members, who were convinced monarchists [6]. 
Prince Vladimir Petrovich Urusov was perhaps the closest and most beloved family member for Sergei. In any case, there is reason to assert that he had a decisive influence on the formation of his personality. All undertakings in horse, poultry, pig and even goat breeding were common to both of them. The magazine "Русский Охотник" (Russian Hunter), published and edited by Vladimir for five years, was eventually taken over by Sergei, who had to continue Vladimir's other endeavors because of his health problems and early death.

Prince Nikolai Petrovich Urusov, it seems, was the only one of the brothers not involved in scientific and literary activities related to agriculture. But it is known that he fully shared the love of his brothers for agriculture, and goat breeding in particular [2]. After the death of Vladimir and Alexander, Nikolai and Sergei became the closest people to each other. After the October Revolution of 1917 they lived together in Yessentuki, and they were arrested and executed together [20].

\section{Upbringing and education}

Prince Sergei Petrovich Urusov was born in Paris on March 9, 1859 [8].

In childhood and adolescence, the fates of Sergei and Vladimir were similar. Prince Sergei Urusov was brought up at home. Both Vladimir and Sergei studied at the Corps of Pages (enlisted in the Pages in memory of the merits of their grandfather, the Actual Privy Councillor Alexander Mikhailovich Urusov (1766 1853)) and concurrently at the Nikolai Cavalry School; but although Vladimir successfully graduated from the Corps of Pages (in 1878), Sergei's name is not mentioned among the graduates of this institution, and he completed his education at the Vilna Infantry Cadet School (in 1880) [7, 9].

\section{Years of military service}

In 1877, Prince Sergei Urusov went to the front. However, he did not join the cavalry, but the 63rd Uglitsky Infantry Regiment, in the rank of a simple soldier "with hunting skills". Almost immediately, he is decorated with a military medal of the IV degree. The battles in which Prince Sergei Urusov participated, namely the Sheinovo battle on December 28, 1877 and the memorable battle near Haskoy on January 7, 1878, are well described in the book by M. N. Yelenev Historical 
Chronicle of the 63rd Infantry Uglitsky Regiment (1908), where a description of the Sheinovo battle by V. I. Nemirovich-Danchenko is included in the appendix. On January 1, 1878, Prince Urusov was promoted to non-commissioned officer. In May of the same year, he was transferred to the Kexholm Grenadier Regiment of the Emperor of Austria. On August 26, 1878, Prince Urusov was promoted into the officer's rank and was assigned back to the 63rd Uglitsky Infantry Regiment. However, apparently, the young Prince Urusov did not want to return there, and in the end he never did.

In September 1879 he came to the Vilna Infantry Cadet School to complete his studies, started in the Corps of Pages and in the Nikolai Cavalry School, and to pass the officer's exam. The decision to complete the education in the province after the privileged metropolitan educational institutions can be partly explained by the fact that in the 1870s his parents' family lived in Vilna. In total, Sergei spent about six months at the Vilna Infantry School. On January 26, 1880, Prince Urusov was enlisted in the 114th Novotorzhsky Infantry Regiment. Apparently, while serving in the infantry units, the young Prince Urusov always had a desire to become a real cavalryman. In 1880, his wishes were fulfilled: he was sent to the 2nd (later 4th) Leib-Dragoon Pskov Regiment of Her Majesty "to learn the rules of combat cavalry service and subsequently transfer to the regiment". In the following year, 1881, Prince Sergei Urusov was officially enlisted in this regiment by the Highest order, but this was accompanied by a demotion from Second Lieutenant to Cornet [9]. Apparently, Urusov's interest in the Russian cavalry, its traditions and history was more than just a hobby. The noble aspiration of the young prince was noticed by the higher military authorities, who managed to put it in the right direction, offering to collect information on the history of the regiment and compile a book on its basis. The prince gladly agreed to do this work in the name of his regiment and the Russian cavalry in general. This was the beginning of his scientific and literary activity, at this stage mainly as a historian-archivist [13].

\section{Years of public service}

\section{Ukrainian period}


After the discharge on May 25, 1883 and before the appointment as a Correspondent at the Main Directorate of State Horse Breeding, several important events took place in the life of Prince Urusov, such as the marriage to Elizaveta Sergeevna Golovina (born May 30, 1863) in 1883 and the birth of his son Petr ((26.08.1885 - after 1920). Elizaveta Sergeevna was the daughter of a prominent statesman Sergei Evgenievich Golovin (1824 - 1889), the governor of Suvlaki, Privy Councilor. Her mother, Elena Pavlovna, née Urusova, was a cousin to Prince Sergei Petrovich Urusov. Accordingly, Prince Urusov's wife was his rather close relative - a cousin niece. Elena Pavlovna owned 22,000 acres of land in the Chernigov province [1], where the young family settled. This moment marks the beginning of the relatively short Ukrainian period in the life of Prince Urusov. But despite the shortness, it became in some way decisive for his entire subsequent life. Having access to vast land resources, he was able to plunge headlong into agriculture and eventually become the famed expert in animal husbandry. It can be assumed that in his estate, like in his brother Alexander's, there were several stud farms, which directly contributed to his formation as a horse breeder.

The public service of Prince Urusov began as a Correspondent at the Main Directorate of State Horse Breeding in the Chernigov province [9, 22]. The activities related to this position are described in the book of V. A. Gilyarovsky "Москва газетная" (Newspaper Moscow). Gilyarovsky held the same position, though much later than Prince Urusov. However, Gilyarovsky's articles were published in Urusov's magazine "Русский спорт" (Russian Sport) long before he took this position.

At first, Prince Urusov lived in Ukraine and conscientiously fulfilled the duties of a Correspondent at the State Administration of Horse Breeding, sending materials for publication, and having gained fame in hippological literature and a certain authority as a horse breeder. During these years, he was regularly promoted in rank, in two years advancing from the Provincial Secretary to the Titular Councilor [22].

\section{Moscow period}

Since the end of 1887, Prince Urusov moved to Moscow and became the chief editor of the horse breeding magazine "Русский спорт" (Russian Sport) [11]. 
The early 1890s marked an important episode in the life of Prince Urusov, which largely predetermined his future activities. In the last years of his stay in Moscow, Urusov became close to the wife of the Moscow Governor-General Elizaveta Fedorovna, becoming a clerk at the Elizabethan Charitable Society organized by her [22]. In subsequent years, Prince Urusov's wife and sisters were involved in this society [10], but later they organized their own charity - the Society of Unity (“Общество Единения”) [10]. Overall, charitable activities were nearly the single most important raison d'être of the members of the Urusov family, which is described in detail in the book by Nedrya and Chernobay.

As it turned out, Sergei was no exception to this family tradition. Moreover, his name can even be distinguished as outstanding. The goal of the Elizabethan Charitable Society was to take care of orphans, illegitimate children, foundlings, as well as children from disadvantaged and poor families. By that time, the Moscow orphanage no longer had capacity to cope with its duties, and it became necessary to create a new special charitable institution to receive children. The merits of Grand Duchess Elizaveta Feodorovna, canonized by the Russian Orthodox Church, were widely discussed in recent decades, but it is seldom mentioned that the main work of organizing her charitable activities was undertaken by Prince Sergei Urusov. His serious attitude to this work can be understood from the fact that he had to leave the Moscow Racing Society [22].

The charter of the Society was approved by Emperor Alexander III on January 17, 1892. The Elizabethan Charitable Society relied on the joint efforts of secular and church organizations in caring for children in need, and it was a complex ramified structure that carried out large-scale charitable activities. The Board of the Society consisted of the Mayor of Moscow, director of the orphanage, doctor, manager, foreman of the merchant class and secretary of Grand Duchess Elizaveta Fedorovna.

Elizabethan committees were set up at all church parishes in Moscow and in all district towns of the Moscow province. Each such committee was headed by the rector of the church, and included the church head and parishioners who were 
members of the Elizabethan Charitable Society. Each committee, as a rule, had complete information about the needs of its parishioners, so that no dysfunctional or needy family was concealed from the attention of the Society. In addition to shelters and nurseries, the work of the Society involved monasteries, vocational schools, private educational institutions, and the Elizabethan temporary shelter for children. The efficiency of this Society was highly appraised by contemporaries who called it "the adornment of Moscow" and "the blossom of Christian mercy" [14]. One way or another, as the head of the Elizabethan Charitable Society, Prince Urusov acquired a unique experience of running the organizations that aimed to solve problems related to the communal well-being, and mainly the poorest segment of the rural population. All his subsequent undertakings of this kind were, as a rule, quite successful.

In general, Prince Urusov and Grand Duchess Elizaveta Fedorovna were brought together not only by charity. Apparently, in those years, Elizaveta Fedorovna was keenly interested in agricultural issues. As we know from the "Земледельческая газета" (Agricultural newspaper) (1893), she and the brothers Vladimir and Sergei Urusov were among the foremost activists of the Moscow Poultry Society, chaired by V. M. Shestakov. Grand Duke Sergei Alexandrovich and Grand Duchess Elizaveta Fedorovna organized the Ilyinskaya farm in their estate, which won excellent reviews for poultry exhibitions, and princes Vladimir and Sergei Urusov presented their Konaevo farm, located in the Moscow district, in their family estate. As witnessed by publications in magazines, the enthusiasm for poultry has remained with Prince Urusov for all of his subsequent life. Poultry farming, along with horse and goat breeding, became one of the main and favorite things in his life. According to the publications in the "Птицеводное хозяйство" (Poultry Industry) magazine, it was at this time that the brothers Vladimir and Sergei Urusov began to breed goats on their farm.

In 1894, Prince S.P. Urusov leaves Moscow, Grand Duchess Elizaveta Fedorovna and the magazine Russian Sport, and moves to St. Petersburg [10, 22]. These changes in his life coincide with the illness and death of Emperor Alexander III and the accession of Nicholas II. 


\section{St. Petersburg period}

After moving to St. Petersburg, Prince S.P. Urusov works in two departments: the Main Directorate of State Horse Breeding and the Ministry of Agriculture and State Property, steadily advancing in rank and position [10, 22].

As for the Main Directorate of State Horse Breeding, Prince Urusov first worked as the editor of the state-owned magazines "Коннозаводство и коневодство" (Horse Breeding) and "Журнал коннозаводства" (Journal of Horse Breeding), then became a member of the Board of the Main Directorate of State Horse Breeding, where he remained until the events of 1917. As for the Ministry of Agriculture and State Property (MASP), Prince Urusov began his activities as a clerk at the Department of Agriculture, then as an official on special assignments at the MASP, as a specialist in animal husbandry, as a member of the Bureau of Animal Science and the Bureau of Commercial Zoology, as a representative of the MASP at the Main Directorate of State Horse Breeding, and finally as an inspector of the Department of Agriculture for the agricultural part. The service of Prince Urusov at MASP continued until his appointment at the Ministry of Internal Affairs in 1913.

In addition, in 1895 he worked as editor-in-chief of the magazine "Русский охотник" (Russian Hunter) and wrote books on various branches of animal husbandry. In 1896, Vladimir and Sergei founded the Russian Society of Agricultural Poultry and its printed organ - the journal "Птицеводное хозяйство" (Poultry Industry), which subsequently had the most direct relation to the development of domestic goat breeding.

The Urusov brothers left a rather deep imprint on the activities of the leading agricultural publication of that time, “Земледельческая газета" (Agricultural Newspaper). Contrary to the name, it was not a newspaper, but a rather voluminous and informative magazine. What made it similar to a newspaper, perhaps, was the fact that it was a weekly publication. Alexander was the first of them who began to cooperate with the Agricultural Newspaper, then, by the early 1890s, Vladimir and Sergei joined in. There was the time when the magazine published three Urusovs at the same time. Having started their activity at the Agricultural Newspaper under the 
leadership of A.F. Batalin, the Urusovs thus gained respect as veterans of this journal.

Long-term involvement of Prince Sergei Urusov in the Agricultural Newspaper fully reveals the breadth of his knowledge in the field of agriculture and related sciences. It shows how alien narrow specialization was for Urusov, how competently and practically he formed an approach to a particular issue of agriculture, with a comprehensive view of the problem. In addition to articles on livestock, he published extensively on feedstuff production and even on agronomy, despite the fact that he has repeatedly denied his competence in this area. In addition, on the pages of the Agricultural Newspaper he proved himself to be a brilliant naturalist, an expert on the peculiarities of various natural and climatic regions of the Russian Empire, excellently versed in geography, soil science and botany.

Urusov devotes special attention in the Agricultural Newspaper to answers to readers' questions, where his breadth of knowledge came in handy.

At one time the editor-in-chief of the Agricultural Newspaper was A. F. Rudzky, who had just begun to work on the famous Complete Encyclopedia of Russian Agriculture, and Prince Urusov was involved in its compilation. In addition to articles on horse breeding, goat breeding, poultry and pig breeding, we see the article "Photographing Farm Animals", where he, among other things, examines the photogrammetric method of Dr. Liebenau, which could be successfully applied in our age of digital cameras and computer programs.

In 1905, Prince Urusov received the rank of General as an Actual State Councilor [10, 22]. During these years, he was actively engaged in the development of the foundations of domestic goat breeding. The culmination of this work was the establishment of the Russian Society of Goat Breeding, in which he was actively involved during the first two years of its operation. However, after the third edition of his book The Goat was published at the end of 1911, Prince Urusov gradually moved away from the active work on goat breeding. On the one hand, having passed the initiative into the hands of his followers, he considered his work done. On the other hand, the new responsibilities entrusted to him, such as the work at the Ministry of 
Internal Affairs and the position of editor-in-chief at the newspaper “Правительственный вестник" (Government Gazette), which also forced him to leave his job at the Department of Agriculture. At the Russian Society of Goat Breeding, he transitioned from the chairman to the honorary chairman, transferring the management, but staying in touch with day-to-day acitivities.

\section{In the court rank}

In 1908, Prince Sergei Urusov received the court title "In the position of equestrian of the Imperial Court of His Majesty" [10, 22]. On the one hand, this title had the meaning of an extraordinary award and special favor from the emperor. But on the other hand, Prince Sergei Urusov receives it, despite all the merits in the field of horse breeding, much later than his younger brother Nikolai. The very title "in the position of equestrian" suggested something like a candidate for this position. Although, as we can see from the address calendars, Princess Elizaveta Sergeevna Urusova after this appointment already had the rights to be called "the equestrian's wife". The title of the actual equestrian of the Court already corresponded to the rank of the III class - the privy councilor, which, as a rule, was appointed after 10 years of service in the rank of the actual state councilor (IV class). Prince Nikolai Petrovich Urusov, in the order of the exceptions that took place, "for distinction" was promoted to privy councilor and equestrian in five years. Sergei was promoted to these ranks after almost ten years of being an actual state councilor - in 1914. As for the direct performance by Prince S. P. Urusov of his duties at court, nothing definite can be said. Such experts in horse breeding as Prince Sergei Urusov, or even like his brother Nikolai, could have provided very significant assistance at court. However, according to S. V. Bogdanov, the court position of the equestrian (as opposed to the chief equestrian) was only honorary, not involving the direct performance of any duties at the court [15]. But another researcher, L. E. Shepelev, does not support such categorical statements, emphasizing the absence of any certainty in the role of both the equestrians themselves and those who have the title "in the position of equestrian" [16]. Whatever it was, but the Empress Alexandra Fedorovna in her letter to Nicholas II, dated April 1915, writes that she did not personally know Prince 
S. P. Urusov, to some extent it confirms the statements of S. V. Bogdanov. We do not yet have any information about whether this acquaintance took place in subsequent years.

\section{Appointment as editor-in-chief of the newspaper "Правительственный} вестник" (Government Gazette), on vacation and in German captivity

According to the signatures of the editors-in-chief, in 1913 the following chain of events was observed in the "Government Gazette": The last issue, signed by A. A. Bashmakov, who headed this publication for about seven years, was published on February 7 (20). The next issue was signed by M. V. Voitsekhovich as the acting editor-in-chief. However, since March 19 (April 1), 1913, the numbers have already been signed by Prince S. P. Urusov, at first also as an acting editor-in-chief, and from 4 (17) April - already as chief editor. On June 1 (14), M. V. Voitsekhovich again became the head of the publication, and remained in this post for exactly one and a half months - until July 16 (29), when Urusov returned.

This absence of Urusov was most likely due to his summer vacation. In the summer of 1914, Prince S. P. Urusov again took a break in the leadership of the "Government Gazette", and, according to the signature of the editor-in-chief under each issue, this happens on Wednesday, May 28 (June 10) 1914. Since that time, Prince S. P. Urusov is replaced first by I. A. Kubasov, then by M. V. Voitsekhovich. Most likely, the photo session in Kotovka (the estate of Prince Nikolai Petrovich Urusov in Yekaterinoslav province), placed by Nikolai Urusov in the family album preserved in the funds of the Dnieper Historical Museum, dates back to this time. During his absence, the assassination of Archduke Franz Ferdinand and the subsequent chain of fatal events that led to the outbreak of the First World War took place. Before the outbreak of the war, Urusov was in Germany, at the International Exhibition in Leipzig, together with A. V. Bellegarde, who headed the Russian department of the exhibition. Knowing about the imminent start of the war, he immediately went to Petersburg to resume his duties.

July 30 (August 12) 1914 K. K. Sakovsky in the magazine "Российское сельскохозяйственное животноводство" (Russian farming animal husbandry) 
publishes the following note: "We are informed that in Germany, a member of the board of the main directorate of the State Horse Breeding, chairman of the Russian goat breeding society, chief editor of the "Government Gazette" Prince S. P. Urusov was detained and declared a prisoner of war. A few days before the declaration of war, Prince Sergei Petrovich left Leipzig, but he failed to cross the border". Apparently, Prince S. P. Urusov somehow managed to quickly get out of captivity, because on the same day when K. K. Sakovsky's note was published, the issue of the “Правительственный вестник" was published, already signed by Prince S. P. Urusov himself. Accordingly, the presence of Prince S. P. Urusov in captivity is known from his own words after a safe return to St. Petersburg.

\section{Service in the Ministry of Internal Affairs}

In 1913, Prince S. P. Urusov was appointed an official of special assignments of the IV class under the Minister of Internal Affairs [10, 22]. An official for special assignments could be assigned duties that were not distributed among other officials of the apparatus. In addition, such an official could perform any work in the ministry, for example, replace an absent member of the minister's council. On the one hand, there was nothing special in the appointment of Prince Urusov to the leadership of the Ministry of Internal Affairs. His brothers, the departed Vladimir and Nikolai, had already passed this path by that time, and Sergei had all the prerequisites to follow in their footsteps. But on the other hand, this appointment coincides with the appointment as editor-in-chief of the "Government Gazette" - and this is an important post in the Main Directorate for Press Affairs, which was one of the organs of the Ministry of Internal Affairs. It is possible that Urusov's duties as an official for special assignments initially consisted of working on "Government Gazette". But this cannot be stated unequivocally, since later, in addition to working on the newspaper, he also performed other functions in the Ministry of Internal Affairs, namely, a member of the minister's council and a deputy minister. Accordingly, being the same official for special assignments, Prince S. P. Urusov could also work in the council of the minister. 
The pre-revolutionary time was turbulent, and for a short time, when Urusov served in the Ministry of Internal Affairs, six interior ministers were replaced:

Maklakov, Nikolai Alekseevich (1871-1918) December 16, 1912 - June 5, 1915

Shcherbatov, Nikolai Borisovich (1868-1943) June 5, 1915 - September 26, 1915

Khvostov, Alexey Nikolaevich (1872-1918) September 26, 1915 - March 3, 1916

Sturmer, Boris Vladimirovich (1848-1917) March 3, 1916 - July 7, 1916

Khvostov, Alexander Alekseevich (1857-1922) July 7, 1916 - September 16, 1916

Protopopov, Alexander Dmitrievich (1866-1918) September 16, 1916-March 13, 1917

After the appointment in 1914 of Prince S. P. Urusov as an equestrian and transferring to the rank of the III class (privy councilor), for some time he was still listed as an "official on special assignments". In early 1916, Prince S. P. Urusov, being already a senator, was appointed a member of the council of the Minister of Internal Affairs (A. N. Khvostov). Towards the end of 1916, he was appointed a comrade (in the modern sense - something like a deputy) of the Minister of Internal Affairs (A. D. Protopopov).

\section{After the February Revolution}

In the dashing time of the overthrow of the monarchy, Prince S. P. Urusov remained the chief editor of the "Government Gazette" (from March 5 (18), 1917 “Вестник Временного правительства" (“the Provisional Government Bulletin”). With his participation, the publication, in spite of everything, continued to work at the same level, the presentation of the material was of the highest quality, what is of no small importance for modern historical researchers concerning those events. However, on May 17 (30), 1917, the last issue of the newspaper was published with the signature of prince S. P. Urusov. Despite the fact that he was replaced by an experienced colleague - M. V. Voitsekhovich, the fate of "Vestnik" after Urusov's departure is very similar to what happened to "Russkiy Sport". What exactly made Prince Urusov leave this publication is unknown to us. There is no doubt that, on duty, he was obliged to keep abreast of all events, some of which forced him to leave Petrograd.

How exactly this happened, we do not know, but it is definitely known that in October 1917, before the October events, he already lived in the resorts of the 
Caucasian mineral waters. At this time his brother Nikolai moved to him with with great difficulty from Ukraine. In addition to them, there were Sergei's wife, Princess Elizaveta Sergeevna Urusova, and the widow of Prince Vladimir Petrovich Urusov, Varvara Vasilievna with her children.

We can judge about life in the Caucasus at that time from the diary of Count Yuri (Georgy) Pavlovich Grabbe, who was then a gymnasium student, (later the notorious Archbishop of the Russian Orthodox Church Outside of Russia, Gregory), who meticulously wrote down the entire course of events at that time. In his notes, he mentions the Urusov brothers several times, and also writes that he personally met with Sergei. From the fragmentary information from Grabbe's diary, it is clear that the Urusovs, even in exile, continued to do their usual business - social work. In particular, it is written that they, together with A. D. Nechvolodov (the author of the famous 4-volume "Tales of the Russian Land"), were organizing church fraternity. The date "June 16" (1918) tells how two Urusovs with a group of people went to the city occupied by the Red Army, immediately after the retreat of Shkuro's detachment.

There's also mentioned a trial of Prince N. P. Urusov: "Monday, June 18th: I went to see A. D. Nechvolodov. He sent me on a mission to Prince Sergei Urusov. All the Urusovs were in terrible excitement, for while the trial of Nikolai Urusov"[17].

In addition to the diary of Yu. P. Grabbe, information about the life of the Urusovs in Yessentuki is contained in the book of memoirs by Olga Alekseevna Villiers (née Kapnist), daughter of Rear Admiral A. P. Kapnist. The Kapnists and Urusovs lived on different floors in one of the houses that belonged to the Makarovs on Batalinskaya Street (now these houses are the buildings of the sanatorium "Шахтер"). The house with the adjoining garden, according to O. A. Villiers herself, made a wonderful impression on the little girl at that time and left the best memories. She says the same about the neighbors, noting that the Urusovs were "great guests, and we got along well with them". She also left a description of the Urusovs' appearance: "There were three of them: Sergei Petrovich, a gray-haired blond, thin and tall, married to a tiny, plump and very pretty Elizabeth ... Younger brother, 
Nikolai Petrovich, a large and cheerful brunette with light gray hair, he told us a lot of interesting things about the remote parts of Russia ..." [18].

\section{Red terror}

The Bolsheviks tried to justify the Red Terror by claiming that it was a response to the so-called "White Terror":

On August 17, 1918, in St. Petersburg, a former student, cadet during the war, socialist Kanegisser killed the People's Commissar of the Northern Commune, the head of the St. Petersburg Extraordinary Commission - Uritsky.

On August 28, the socialist Kaplan attempted the life of Lenin in Moscow ...

However, the Bolshevik leaders were actually killed by the SocialistRevolutionaries and anarchists. For them, it was a kind of "usual thing". Previously, they terrorized the "tsarist satraps", after 1917 - communist leaders [19].

\section{Hostage arrest history}

On September 4, 1918, followed an order from the People's Commissar of Internal Affairs Grigory Petrovsky, in which, in response to the murders of Moisey Volodarsky, Moisey Uritsky, attempts on the life of Vladimir Lenin, "mass shootings of comrades" and "constant conspiracies," it was ordered to "take a significant number of hostages from the bourgeoisie and officers" and shoot them at the slightest attempt at resistance. Local executive committees were instructed to show special initiative in this direction.

The impetus for the immediate implementation of this directive were the raids of the colonel, in the near future a general and one of the prominent commanders of the White movement, Andrei Shkuro, on Stavropol, Essentuki and Kislovodsk. In the summer and especially in the fall of 1918 in the cities of the so-called Caucasian Mineral Group (Pyatigorsk, Essentuki, Kislovodsk, Zheleznovodsk, etc.), a series of arrests of people who permanently resided in these resorts or who tried to hide here from the threat of the October Revolution and the Civil War swept through. Prince S. P. Urusov was arrested together with his brother Nikolai in Yessentuki on September 11, together with other prisoners, representatives of the highest nobility and officers were kept in the New European hotel in Pyatigorsk [20]. 


\section{Hostage execution history}

Ivan Lukich Sorokin, commander-in-chief of the Red Army of the North Caucasus and one of the most talented Red generals, discovered a conspiracy among the members of the Central Executive Committee of the North Caucasian Soviet Republic, the purpose of which was to eliminate him. On October 21, 1918, acting proactively, he arrests the top of the Central Executive Committee: Abram Izrailevich Rubin, Viktor Krainiy (M. I. Schneidermann), Boris Grigorievich Rozhansky, Semyon Abramovich Dunaevsky.

On the way of the convoy, the aforementioned persons resisted and were shot, though it was not originally planned.

As a result, this so-called "Sorokin adventure", which cost the life for Sorokin himself, served as a trigger for the brutal massacre of the Pyatigorsk hostages, which became an act of intimidation and at the same time revenge for the execution of the leaders of the NCSR [21].

On the night of October 18-19, 1918, Prince S. P. Urusov was brutally killed along with 58 other prisoners, who were taken to the cemetery to a specially dug pit, near which they were killed without the use of firearms: with sabers, bayonets and rifle butts. The organizers of the atrocity were the Bolsheviks Stelmakhovich, Kravets, Ge and Atarbekov. Among those killed were such celebrities as General Ruzsky (the one who forced Nicholas II to abdicate), General Prince A. I. Bagration Mukhransky, Rear Admiral Count A. P. Kapnist and others, as well as the prince Sergei Petrovich Urusov's brother - Nikolay [20].

The Pyatigorsk massacre was openly and sharply condemned by S. M. Kirov, S. Ordzhonikidze and other Bolshevik leaders, including Lenin himself, but Atarbekov and others like him were not punished.

\section{Reburial}

After the occupation of the Caucasus by the White Army, on February 27, 1919, a Special Commission to Investigate the Atrocities of the Bolsheviks, consisting of the Commander-in-Chief of the Armed Forces in the South of Russia, began the excavation of two graves in which the bodies of the killed hostages were dumped. 
The exhumed corpse, placed in coffin № 5, was identified as belonging to Prince Sergei Petrovich Urusov [20].

From the memoirs of the son of Colonel Popov, who was executed there: "There was a solemn funeral. They served a requiem. In the square in front of the cathedral, many closed coffins covered with pine branches were placed on the ground. Candles were burning ... Later I visited the cemetery church and the mass grave, which was located within the fence, in a glade south of the church. The grave was framed by a low wooden fence, painted along the perimeter in the form of a St. George ribbon" [18].

From these words, it is assumed that at that time the fence of the temple covered a larger territory than it is now, and on the site of the mass grave, south of the temple, there is now a spruce forest. Two graves, where the Bolsheviks originally dumped the bodies of the killed hostages, were located there, on the territory of the Pyatigorsk necropolis. Their exact location is indicated in the collection book "The Red Terror during the Civil War" (2004): "The first grave was located in the northwestern corner of the Pyatigorsk city cemetery, at a distance of 19 fathoms from the western wall of the cemetery and four and a third fathoms from its northern wall". "On February 28 and March 1, 1919, at the foot of the town of Mashuk, at the Pyatigorsk hospital (cholera) cemetery, the second grave of the hostages killed in October was excavated 1918, which grave is located at a distance of two arshins from the grave of Babkova and 5 yards 1 arshin from the northeastern corner of the city's Orthodox cemetery" [20].

Thus, during his 35-year active career, Prince Sergei Petrovich Urusov made a significant contribution to the formation of research work in animal husbandry as the head of special periodicals, as a specialist in the Department of Agriculture and the Main Directorate of State Horse Breeding, as an organizer of extremely successful social work, such as for planting different branches of animal husbandry in the Russian Empire. Among his merits, special mention should be made of his scientific and literary activity as the author of more than 50 books on various branches of animal husbandry and a huge number of articles in various agricultural periodicals. 
The activity of Prince Sergei Petrovich Urusov falls on the years when the foundations of Russian zootechnical science were formed. Without exaggeration, we can say that he is one of the key figures in this process. Considering the exceptionally active and varied activities of Prince Urusov in the field of animal husbandry, the contribution of this scientist without exaggeration can be called large and comprehensive, and he himself deserves to be mentioned on a par with the famous founders of Russian zootechnical science.

\section{Список використаних джерел і літератури}

1. Нарбут А.Н. Родословные росписи. Выпуск 2. Князья Урусовы. М., 1994. $56 \mathrm{c}$.

2. Недря, К.М., Чорнобай П. О. Почесний громадянин міста Катеринослава - князь М. П. Урусов. Суспільно-політичний портрет- Д.: Національний гірничий університет, 2013. - 159 с.

3. Российский государственный военно-исторический архив, ф. 400, оп. 14 , д. 6716, л. 13-16. Формулярный список о службе члена Виленской комиссии по крестьянским делам при Виленском, Ковенском. Гродненском и Минском генерал-губернаторе, камергера Двора Е. И. В., действительного статского советника князя Урусова. Составлен по 14 февраля 1870 года.

4. Голицын Н. Н. Библиографический словарь русских писательниц Санкт-Петербург : тип. В.С. Балашева, 1889. - VI, 308 с.; 23.

5. Бельгард. А. В. Воспоминания - Москва : Новое литературное обозрение, 2009. - 684, [1] с., [8] л. ил., портр., факс. : ил.; 22 см.

6. Российский государственный исторический архив, Ф. 1278. Оп. 9. Д. 820. Князь Александр Петрович Урусов (1850 - 1914) (биографические сведения).

7. Российский государственный исторический архив, Ф. 776, оп. $22-$ 1902 , д. 10. Князь Владимир Петрович Урусов $(1857$ - 1907) (биографические сведения).

8. Российский государственный исторический архив, Ф 1343 оп. 46 д. 812 л. 464. Свидетельство о рождении и крещении князя Сергея Петровича Урусова.

9. Российский государственный исторический архив, Ф. 1349 оп.3 д. 2308 л. 80 - 84. Формулярный список о службе корреспондента Главного Управления Государственного Коннозаводства по Черниговской губернии, губернского секретаря князя Урусова Сергея Петровича.

10. Весь Петербург - адресная и справочная книга Санкт-Петербурга, изд. А. С. Суворина (1894 - 1917) (с 1915 по 1917 год - “Весь Петроград”).

11. Вся Москва - адресная и справочная книга города Москвы, изд. А. С. Суворина (1872 - 1917). 
12. Альбом князя Петра Александровича Урусова / Гос. литературный музей ; [авт.-сост.: Л. И. Морозова]. - Москва : Три квадрата, 2015. - 157, [2] с. : ил., цв. ил.; 24х30 см.

13. Князь Урусов С. П. История 4-го Лейб-драгунского Псковского Ее Величества полка 1701-1883 гг. - Санкт-Петербург : типо-лит. А.М. Вольфа, 1883. - XXVIII, 436, 190 с. ; 23 см.

14. Максимова Л. Б. Елизаветинское благотворительное общество в $\begin{array}{lllllll}\text { Москве и Московской губернии (1892 } & -1917 & \text { г.г.) }\end{array}$ http://www.rondtb.msk.ru/info/ru/Maksimova_ru.htm

15. Богданов С. В. Придворный штат императора Николая II/ Вестник Пермского университета вып. 4 (39), 2017, стр. 67.

16. Шепелев Л. Е. Титулы, мундиры и ордена Российской империи - М. : Центрполиграф ; Спб. : МиМ-Дельта, 2004 (ГУП ИПК Ульян. Дом печати). 420, [3] с., [32] л. цв. ил., портр. : ил., портр., табл.; 22 см.

17. Граф Ю. П. Граббе. Дневник (http://portalcredo.ru/site/?act=lib\&id=1319).

18. Вильерс О. А., В. Попов Воспоминания русской бабушки/ Пятигорская трагедия - Москва : Энциклопедия сел и деревень, 2005 - 333, [2] с., [16] л. ил. : ил., факс.; 22 см.

19. Мельгунов, С. П. Красный террор в России, 1918-1923 - Симферополь : Таврия, 1991. - 253,[2] с.; 20 см.

20. Красный террор в годы Гражданской войны : По материалам Особой следств. комис. по расследованию злодеяний большевиков : [Сб. докум.] / Под ред. Ю. Г. Фельштинского и Г. И. Чернявского. - М. : Терра-кн. клуб, 2004. 508, [1] с.; $21 \mathrm{~cm}$.

21. Крутоголов Ф. Ф. Правда о Сорокине/ Новейшая история России 2012 №3 c. $260-274$.

22. Адрес-календарь: Общая роспись начальствующих и прочих должностных лиц по всем управлениям в Российской Империи - СанктПетербург, типография Правительствующего Сената, 1859 - 1916.

\section{References}

1. Narbut A.N. (1994) Rodoslovnye rospisi. Vypusk 2. Knjaz'ja Urusovy [Pedigrees genealogical. Issue 2. Princes Urusov]. Moscow [in Russian].

2. Nedria, K.M., Chornobai P. O. (2013) Pochesnyi hromadianyn mista Katerynoslava - kniaz M.P. Urusov. Suspilno-politychnyi portret [Honorary citizen of the city of Ekaterinoslav - Prince MP Urusov. Socio-political portrait] - Dnipro: Natsionalnyi hirnychyi universytet, [in Ukrainian].

3. Rossiyskiy gosudarstvennyy voenno-istoricheskiy arkhiv, f. 400, op. 14, d. 6716, 1. 13-16. Formuljarnyj spisok o sluzhbe chlena Vilenskoj komissii po krest'janskim delam pri Vilenskom, Kovenskom. Grodnenskom i Minskom generalgubernatore, kamergera Dvora E. I. V., dejstvitel'nogo statskogo sovetnika knjazja Urusova. Sostavlen po 14 fevralja 1870 goda [Formular list about the service of a member of the Vilna commission on peasant affairs at Vilna and Kovno. Governor- 
General of Grodno and Minsk, Chamberlain of the Court, actual state councilor Prince Urusov. February 14, 1870]. [in Russian].

4. Golicyn N. N. (1889). Bibliograficheskij slovar' russkih pisatel'nic [Bibliographic Dictionary of Russian Female Writers] - Sankt-Peterburg : tip. V.S. Balasheva [in Russian].

5. Bel'gard. A. V. (2009). Vospominanija [memoirs]- Moskva : Novoe literaturnoe obozrenie [in Russian].

6. Rossiyskiy gosudarstvennyy istoricheskiy arkhiv, F. 1278. Op. 9. D. 820. Knjaz' Aleksandr Petrovich Urusov (1850 - 1914) (biograficheskie svedenija) [prince Alexander Petrovich Urusov. biographical information] [in Russian].

7. Rossiyskiy gosudarstvennyy istoricheskiy arkhiv, F. 776, op. $22-1902$, d. 10. Knjaz' Vladimir Petrovich Urusov (1857 - 1907) (biograficheskie svedenija) [prince Vladimir Petrovich Urusov. biographical information] [in Russian].

8. Rossiyskiy gosudarstvennyy istoricheskiy arkhiv, F. 1343 op. 46 d. 8121. 464. Svidetel'stvo o rozhdenii i kreshhenii knjazja Sergeja Petrovicha Urusova [Birth and baptism certificate of Prince Sergei Petrovich Urusov] [in Russian].

9. Rossiyskiy gosudarstvennyy istoricheskiy arkhiv, F. 1349 op.3 d. 23081.80 - 84. Formuljarnyj spisok o sluzhbe korrespondenta Glavnogo Upravlenija Gosudarstvennogo Konnozavodstva po Chernigovskoj gubernii, gubernskogo sekretarja knjazja Urusova Sergeja Petrovicha (1886) [Formular list about the service of the correspondent of the Main Directorate of the State Horse Breeding in the Chernigov province, the provincial secretary of Prince Urusov Sergei Petrovich (1886)]. [in Russian].

10. Ves' Peterburg - adresnaja i spravochnaja kniga Sankt-Peterburga(1894 1917) (1915 - 1917 - "Ves' Petrograd") [All Petersburg - address and reference book of St. Petersburg] izd. A. S. Suvorina [in Russian].

11. Vsja Moskva - adresnaja i spravochnaja kniga goroda Moskvy(1872 1917) [All Moscow - address and reference book of the city of Moscow] izd. A. S. Suvorina [in Russian].

12. Morozova L. I. (2015). Al'bom knjazja Petra Aleksandrovicha Urusova [Album of Prince Petr Alexandrovich Urusov] / Gos. literaturnyj muzej - Moskva : Tri kvadrata [in Russian].

13. Knjaz' Urusov S. P. (1883). Istorija 4-go Lejb-dragunskogo Pskovskogo Ee Velichestva polka 1701-1883 gg. [History of Her Majesty's 4th Leib-Dragoon Pskov Regiment 1701-1883] - Sankt-Peterburg : tipo-lit. A.M. Vol'fa [in Russian].

14. Maksimova L. B. Elizavetinskoe blagotvoritel'noe obshhestvo v Moskve $i$ Moskovskoj gubernii (1892-1917 g.g.) [Elizabethan Charitable Society in Moscow and Moscow Province (1892-1917)] Retrieved from

http://www.rondtb.msk.ru/info/ru/Maksimova_ru.htm [in Russian].

15. Bogdanov S. V. (2017) Pridvornyj shtat imperatora Nikolaja II [Court staff of Emperor Nicholas II] Vestnik Permskogo universiteta [Perm University Bulletin] 4 (39), 67 [in Russian].

16. Shepelev L. E. (2004) Tituly, mundiry i ordena Rossijskoj imperii - Moscow : Centrpoligraf ; Sankt-Peterburg [Titles, uniforms and orders of the Russian Empire]: MiM-Del'ta, (GUP IPK Ul'jan. Dom pechati) [in Russian]. 
17. Graf Ju. P. Grabbe. Dnevnik [Memoirs] Retrieved from

http://portal-credo.ru/site/?act=lib\&id=1319)[in Russian].

18. Vil'ers O. A., V. Popov (2005) Vospominanija russkoj babushki/ Pjatigorskaja tragedija [Memories of a Russian grandmother / Pyatigorsk tragedy] Moskva : Enciklopedija sel i dereven' [in Russian].

19. Mel'gunov, S. P. (1991) Krasnyj terror v Rossii 1918-1923 [Red terror in Russia 1918-1923] - Simferopol' : Tavrija [in Russian].

20. Krasnyj terror v gody Grazhdanskoj vojny : Po materialam Osoboj sledstv. komis. po rassledovaniju zlodejanij bol'shevikov [The Red Terror during the Civil War: Based on materials from Special Investigations commission on the atrocities of the Bolsheviks] [Sb. dokum.] Pod red. Ju. G. Fel'shtinskogo i G. I. Chernjavskogo (2004). - Moscow : Terra-kn. Klub [in Russian].

21. Krutogolov F. F. (2012) Pravda o Sorokine [The truth about Sorokin] Novejshaja istorija Rossii [Contemporary history of Russia] 3, $260-274$ [in Russian].

22. Adres-kalendar': Obshhaja rospis' nachal'stvujushhih i prochih dolzhnostnyh lic po vsem upravlenijam v Rossijskoj Imperii [Address-calendar: General list of superiors and other officials for all departments in the Russian Empire] (1859 - 1916) Sankt-Peterburg, tipografija Pravitel'stvujushhego Senata [in Russian].

Рецензент:

Гутник М. В., к.і.н., доцент

Радогуз С. A., к.і.н.

Надійшла до редакції 29.07.2020 p. 